\title{
Understanding the challenges faced by Michigan's family farmers: race/ethnicity and the impacts of a pandemic
}

\author{
Dorceta E. Taylor ${ }^{1} \cdot$ Lina M. Farias ${ }^{2} \cdot$ Lia M. Kahan $^{3}$ - Julia Talamo ${ }^{1}$ - Alison Surdoval ${ }^{4}$ - Ember D. McCoy ${ }^{5}$. \\ Socorro M. Daupan ${ }^{6}$
}

Accepted: 3 February 2022 / Published online: 3 March 2022

(c) The Author(s) 2022

\begin{abstract}
Michigan is a critical agricultural state, and small family farms are a crucial component of the state's food sector. This paper examines how the race/ethnicity of the family farm owners/operators is related to farm characteristics, financing, and impacts of the pandemic. It compares 75 farms owned/operated solely by Whites and 15 with People of Color owners/operators. The essay examines how farmers finance their farm operations and the challenges they face doing so. The article also explores how the Coronavirus-19 (COVID-19) pandemic affected farming operations, the financial viability of farms, and how farmers responded to the challenges posed by the pandemic. The study found that People of Color farm owners/operators were younger than White farm owners/operators. The People of Color farm owners/operators tended to manage smaller farms for shorter periods than White farm owners/operators. Though two-thirds of the Farmers of Color owned their farms, they were more financially vulnerable than White farm owners/operators. The farmers studied had difficulty obtaining loans to finance their farms. Farmers reported increasing requests from people for food assistance during the pandemic. Farmers responded to the pandemic by participating in government programs such as the Farm to Families Food Box Program that purchased their produce. It allowed farmers to supply emergency food assistance programs with products from their farms. The products went to families receiving food assistance from soup kitchens, food banks, and other community-based nonprofits.
\end{abstract}

Keywords COVID $\cdot$ Loans $\cdot$ Financial insecurity $\cdot$ People of Color $\cdot$ Whites $\cdot$ Organic $\cdot$ Food insecurity $\cdot$ Food assistance $\cdot$ Gleaning $\cdot$ Online

\section{Abbreviations \\ BIPOC Black, Indigenous, and People of Color \\ CARES Coronavirus Aid, Relief, and Economic Stability \\ CFAP Coronavirus Food Assistance Program}

COVID Coronavirus Disease

CSA Community-supported agriculture

EIDL Economic Injury Disaster Loans

FFFBP Farmers to Families Food Box Program

FSA Farm Service Agency

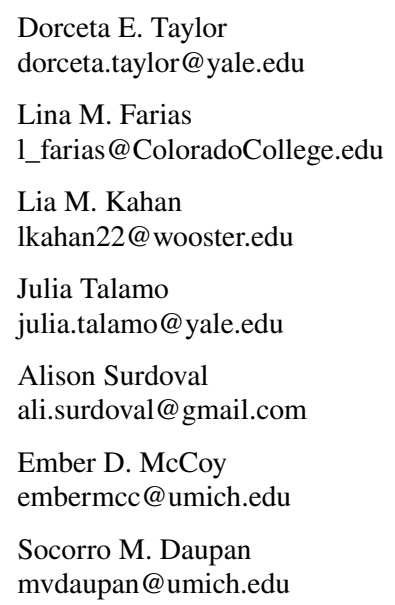

1 School of the Environment, Yale University, 195 Prospect Street, New Haven, CT 06511, USA

214 E Cache La Poudre St, Colorado Springs, CO 80903, USA

3 The College of Wooster, 1189 Beall Ave, Wooster, OH 44691, USA

4 The Nature Conservancy, 4245 North Fairfax Drive, \#100, Arlington, VA 22203, USA

5 School for the Environment and Sustainability, University of Michigan, 440 Church Street, Ann Arbor, MI 48109, USA

6 Clean Water Action, 1315 Walnut Street, Philadelphia 19107, USA 
PPE Personal Protective Equipment

PPP Paycheck-protection program

LGBTQ Lesbian, gay, bisexual, transgender, and queer

MDARD Michigan Department of Agriculture \& Rural Development

MEDC Michigan Economic Development Corporation

USDA United States Department of Agriculture

\section{Introduction}

Despite the consolidation of farms and a shift to more extensive farming operations over the past three decades, most of the farms in the U.S. are still small, family-run operations. That is, $89.9 \%$ of the farms in America are considered small. Small farms average 231 acres in size and are typically family operated ${ }^{1}$ (MacDonald et al. 2018; Hoppe 2017; Carlisle et al. 2019; Dunckel 2013). The U.S. Department of Agriculture (USDA) defines a farm as small if it has gross cash farm income under $\$ 350,000^{2}$ (Whitt 2021; MacDonald et al. 2018; Hoppe 2017). This research article examines family farm operators in Michigan because the state has a significant agricultural sector. These types of farms play vital roles in food production in the state. In the U.S., $76 \%$ of farms have annual sales below $\$ 50,000$. Moreover, $58 \%$ of the farms had sales of less than $\$ 10,000$ annually (USDA 2019d). In Michigan, 76\% have lower sales than $\$ 50,000$, and $57 \%$ of the farms have less than $\$ 10,000$ in sales (USDA 2019a).

The 2017 Census of Agriculture reports that 47,641 farms occupy roughly 9.8 million acres in Michigan. The average size of those farms is 205 acres. Like the rest of the country, Michigan is losing its farms. Nationwide, the number of farms fell by $3.2 \%$ between 2012 and 2017 . However, Michigan-which had 56,014 farms in 2007-lost $17.6 \%$ of those farms a decade later (USDA 2019a, b).

It is also vital to study farms and farm owners/operators because the USDA reports that farmers are experiencing rising financial insecurity. Studies show that since 2012, farm sales have declined, and farm debt has increased across the country. It is particularly true of small farms. When profit margins are examined, the status of more than half of all

\footnotetext{
${ }^{1}$ Only $1.2 \%$ of U.S. farms are nonfamily farms. It means that the principal operator and those related to the primary operator do not own a majority share of the business (Hoppe 2017).

${ }^{2}$ Midsize farms have gross cash farm incomes between $\$ 350,000$ and $\$ 999,999$; they comprise $6 \%$ of all farms. There are two categories of large-scale farms (constituting 2.9\% of all farms): large farms have gross cash incomes of between $\$ 1,000,000$ and $\$ 4,999,999$, and very large farms have gross cash farm incomes of more than $\$ 5,000,000$ or more (Hoppe 2017).
}

small farms is considered a high or medium risk for financial problems (Key et al. 2019; Hoppe 2017; Carlisle et al. 2019).

Farmers as so financially stressed that studies show that many need to have off-farm jobs to make ends meet (USDA 2019d; Carlisle et al. 2019). The value of the products sold by Michigan's farmers was $\$ 8.2$ billion in 2017 ; however, the amount of the sales was 5\% lower than it was in 2012. Over the same period, government assistance to farmers had increased by $7 \%$.

Farm production expenses had also risen by $4 \%$ (USDA 2019a). Michigan produces one of the most diverse sets of crops in the nation (Matts et al. 2015). The state ranks 18th overall in the sale of farm produce, 15 th in the production of crops, and 21st in livestock production. Michigan is the fifth largest producer of fruits, tree nuts, and berries and the sixth-largest producer of nursery, greenhouse, floriculture crops, and sod. The state ranks seventh in milk production from cows and tenth in vegetable, melon, potato, and sweet potato production.

Michigan is also the 11th largest producer of hogs and pigs in the country (USDA 2019a).

People from a variety of backgrounds farm in Michigan. Ergo, this paper examines how the race/ethnicity of the family farm owners/operators is related to farm characteristics, financing, and impacts of the pandemic. The essay examines how farmers finance their farm operations and the challenges they face in doing so. It compares farms operated by Whites and People of Color in the state. The article is one of the first to explore how the Coronavirus-19 (COVID-19) pandemic affected farming operations, the financial viability of farms, and how farmers responded to the challenges posed by the pandemic.

Why study the relationship between race/ethnicity and farm ownership and operation? Race/ethnicity is an essential factor influencing becoming a farmer and being successful at it. Nationally, White farm owners generate $98 \%$ of all farm-related income. Typically, Farmers of Color own less land and generate much smaller incomes than White farmers. Farmers of Color are also more likely to rent or lease the farms they operate than White farmers (Carlisle et al. 2019; Horst and Marion 2019). There is ample documentation that the USDA systematically discriminated against Blacks, Native Americans, Latinx, and women farmers by denying them credit to operate their farms (Taylor 2018; Daniel 2013; Minkoff-Zern and Sloat 2017; Carlisle et al. 2019). Consequently, this first-of-a-kind study examines People of Color owned/operated farms to provide vital information about their practices and viability in the pandemic era. 


\section{The demographic characteristics of Michigan's farmers}

The state's farming sector is predominantly White. Hence, $98.2 \%$ of the farmers in the state are White. Black farmers in Michigan account for $0.4 \%$ of the farmers, Native Americans constitute $0.4 \%$, Asians comprise $0.2 \%$, and Latinx farmers make up 1.3\% of the farmers (USDA 2019a, b, c; White and King 2019). Michigan's farmers are also overwhelmingly male; $64.8 \%$ are male, and $35.3 \%$ are female. Michigan mirrors the national trend; $36 \%$ of all producers nationwide are female. The national average age of farmers is $\mathbf{5 7 . 5}$ years of age. Michigan's farmers also tend to be older than the rest of the state's population; $31.2 \%$ are 65 years and older, 59.8\% are between 35 and 64 years old, and a mere $9 \%$ are less than 35 years old.

A 2012 study of 311 of Michigan's organic farmers found that $85 \%$ were male. This study found that $28 \%$ of the farmers were 65 years or older (Matts et al. 2015). Miller and McCole (2014) studied 37 farmers in Southeast Michigan and found that $74.3 \%$ were male. The researchers also found that $19 \%$ of the farmers in their study were 60 years and older.

Studies of Michigan's farmers usually ignore how the race or gender of the farm operators influence action (see, for example, Montri et al. 2021). However, one study that examines 32 female farmers in Michigan's Lower Peninsula assessed the relationship between women, farming, and empowerment (Wright and Annes 2016).

A recent study of 27 farmers in Michigan shows that $59 \%$ of them own their farm, while $11 \%$ rent, lease, or borrow the land they farm (Montri et al. 2021). Scholars also report that some of Michigan's farms struggle financially (Black and Jones 2019). Data showing that 37\% of farmers in Montri et al.'s (2021) study rely on off-farm income to support their businesses lend credence to this claim.

The financial insecurity in Michigan's farming sector is troubling. Studies have shown that Farmers of Color in Michigan experience discrimination in gaining access to farmlands and obtaining loans and grants to finance their farms (Taylor 2018; Tyler et al. 2014). Consequently, the paper assesses if and how Farmers of Color can finance their farms and cope with the disruptions that the pandemic caused.

\section{Farmers and government's response to COVID-19}

The pandemic has had far-reaching impacts on farm owners/operators. Benton (2020), Dickinson (2020), and Emmad and Peña (2020) argue that the pandemic laid bare the fragility of the food system as disruptions in the supply chain created food shortages in some places. Moreover, farmers had a surplus of milk or other foods on their hands because restaurants, schools, and colleges closed. The pandemic also meant that farmers had to decide how early they could start working in their fields, how many people they could hire, what to grow or produce, and where and how to process the products from their farms. Consequently, BlayPalmer et al. (2020) predict that the pandemic will transform the food system because of the adjustments farmers and other food actors make in response to COVID-19. For example, the researchers argue that many food producers will move some of their operations online.

Farmers who experienced market disruptions and other costs associated with COVID-19 are eligible to apply to the Farm Service Agency (FSA) for assistance through the Coronavirus Food Assistance Program (CFAP) (Farm Service Agency 2020). In addition, the USDA approved a $\$ 4.5$ billion package to connect producers with consumers through the Farmers to Families Food Box Program (FFFBP). The program helped producers sell foods originally intended for restaurants (Agricultural Marketing Service 2021; Galloway 2020). The USDA contracted with distributors and wholesalers to provide pre-packed boxes of fresh produce, dairy, and meat to food banks, faith-based organizations, and local nonprofits to distribute to families in need of food. The food boxes contained several Michigan products such as apples, asparagus, bell peppers, blueberries, bratwurst, cabbage, carrots, celery, cheese, concord grapes, cucumbers, fall squash, onions, peaches, potatoes, tomatoes, yellow squash, and zucchini (Sielski 2020). According to the Agricultural Marketing Service (2021), between May 15 and December 31, the FFFBP delivered 132.7 million boxes of food to families nationwide. In Michigan, one distributor-Eastern Market—packaged and delivered 2000 food boxes to food banks and other nonprofits weekly (Galloway 2020).

\section{Methodology}

\section{Definition of farm size}

We use the USDA's definition of farm size to guide our identification and selection of farmers for our study. A farm is an agricultural operation that generates at least $\$ 1000$ in annual sales. Most of the farmers included in our study operate farms with yearly revenues of less than $\$ 350,000$. Hence, we classify them as small farmers (Whitt 2021; MacDonald et al. 2018; MacDonald 2017; Hoppe 2017). Only six of the farmers in the sample had farm revenues that exceeded $\$ 350,000$.

Another indicator of size is the acreage of the farm. All but three of the farmers in the study operate farms that are smaller than 180 acres. A small farm is under 180 acres 
(North Carolina Department of Agriculture 2020). MacDonald et al. (2013) also use acreage to help classify farms. For this study, we will examine the following categories of farms: under 20 acres, farms that are 20-99 acres, and those that are 100 acres or more. We will also analyze farms with the following revenue streams: those for which the revenue was unknown, farms with incomes of \$1000-\$99,000, and those with revenues of $\$ 100,000$ or more.

\section{Defining farm owners/operators and race/ethnicity}

The terms farm owners, farm operators, and farmers are used interchangeably in this paper to refer to the people who own or operate the farms in the sample. Some respondents own the land they farm, while others rent, lease, or borrow land to operate farms on them. The three terms describe the primary or secondary owners/operators. We categorize a farm as owned/operated by Whites if the farm has a sole owner/ operator who is White or a primary and secondary owner/ operator who is White. In other words, no People of Color own/operate the farm in a primary or secondary capacity.

We categorize a farm as People of Color owned/operated if the sole owner/operator is a Person of Color. If either the farm's primary or secondary owner/operator is also a Person of Color, we categorize the farm as a People of Color owned/ operated entity. Thus, if at least one of the farm's primary or secondary owners/operators is a Person of Color, the farm is considered Person of Color owned/operated.

\section{Survey methodology: identifying and selecting family farmers in Michigan}

We studied family farming operations in Michigan during the summer and fall of 2020. We used the Agricultural Marketing Service (2020) directory to identify Michigan farms. We also used the following directories to identify farms: the West Michigan Growers Group, West Michigan Farms to Visit, West Michigan Farm Link, Michigan U-Pick Farms, West-Central Michigan U-Pick Farms, Discover Michigan Farm Fun Directory, Michigan Farm Bureau's Agritourism Directory, Michigan Organic Food and Farm Alliance, and the Upper Peninsula Food \& Farm Directory.

We communicated with 300 farmers we had contact information for to ask them to complete a survey about the farm they operate. The survey, designed on a Qualtrics platform, could be administered by telephone, or self-administered (Qualtrics 2020). Farmers were usually too busy during daytime hours to take a telephone survey, so we sent them a hyperlink to the survey to complete at their convenience. Farmers were offered $\$ 35$ in compensation for their time if they completed the survey; it took about $45 \mathrm{~min}$ to complete the instrument. We surveyed from June 12, 2020, to February 5, 2021. We received 205 responses. One hundred and thirty-seven of the responses were usable. However, this study analyzes 90 farm operations that meet the outlined criteria. We downloaded data from the Qualtrics survey into SPSS 27.0 for statistical analysis (IBM 2020).

\section{Coding open-ended responses and identifying themes}

In addition to the close-ended responses discussed throughout the paper, we discuss responses from four open-ended questions that farmers answered. Farmers who said they faced challenges in obtaining farm financing also reported what challenges they encountered.

We used the participants' responses to create the 32 categories in Table 4. While some farmers faced single obstacles, others faced multiple challenges. We coded each unique challenge into a separate category.

We asked farmers to say what kinds of government assistance programs they gained access to during the pandemic. We used the open-ended responses to identify the government programs that assisted them. We coded each unique program that farmers listed separately (see Table 5).

Respondents indicated how they felt about government responses to farmers during the pandemic. We coded the answers into one of four categories: (a) responses that criticized the government; (b) ambivalent responses-these comments were simultaneously non-judgmental, critical, and supportive of the government; (c) responses that supported the government; and (d) answers in which the respondent said they did not know about government pandemic responses. We present the result of this analysis in Table 6.

Study participants also provided open-ended responses to describe how they responded to the pandemic. Respondents typically described several changes they made on their farms or strategic shifts they made. We coded each unique pandemic response into a separate category. Table 9 contains a list of all the categories.

\section{Results}

\section{Farm locations}

This article analyzes 90 farms. Eighty (88.9\%) are in the state's Lower Peninsula; ten or $11.1 \%$ of the farms are in the Upper Peninsula. The farms tend to be in rural townships; they also hug the "fruit belt" along the Eastern shores of Lake Michigan. 
Table 1 Demographic characteristics of farm owners/operators

\begin{tabular}{|c|c|c|c|c|c|c|}
\hline \multirow[t]{2}{*}{ Characteristics } & \multicolumn{2}{|c|}{ Total owners/operators } & \multicolumn{2}{|c|}{ Primary owners/operators } & \multicolumn{2}{|c|}{ Secondary owners/operators } \\
\hline & Number $(n=144)$ & Percent & Number $(n=90)$ & Percent & Number $(n=54)$ & Percent \\
\hline \multicolumn{7}{|l|}{ Race or ethnicity } \\
\hline White & 127 & 88.2 & 80 & 88.9 & 47 & 87.0 \\
\hline People of Color & 17 & 11.8 & 10 & 11.1 & 7 & 13.0 \\
\hline \multicolumn{7}{|l|}{ Sex } \\
\hline Male & 78 & 54.2 & 55 & 61.1 & 23 & 42.6 \\
\hline Female & 66 & 45.8 & 35 & 38.9 & 31 & 57.4 \\
\hline \multicolumn{7}{|l|}{ Work on the farm } \\
\hline Works full time & 85 & 59.0 & 63 & 70.0 & 22 & 40.7 \\
\hline Works part time & 55 & 38.2 & 27 & 30.0 & 28 & 51.9 \\
\hline \multirow{2}{*}{$\begin{array}{l}\text { Does not work on the farm } \\
\text { at all }\end{array}$} & 4 & 2.8 & & & 4 & 7.4 \\
\hline & Number & Mean age & Number & Mean age & Number & Mean age \\
\hline Mean age (in years) & 144 & 53.9 & 90 & 53.4 & 54 & 54.7 \\
\hline White & 127 & 54.7 & 80 & 54.7 & 47 & 54.5 \\
\hline Person of Color & 17 & 48.0 & 10 & 42.7 & 7 & 55.6 \\
\hline Male & 78 & 54.7 & 55 & 55.3 & 23 & 53.2 \\
\hline Female & 66 & 52.9 & 35 & 50.4 & 31 & 54.7 \\
\hline
\end{tabular}

\section{Demographic characteristics of farm owners and operators}

We collected information on primary and secondary farm owners and operators. Hence, we collected data on 144 farm owners/operators. The majority, $88.2 \%$ (127), of the owners/operators were White, and $11.8 \%$ or 17 of the owners/operators were People of Color (Table 1). Eighty of the $127(63 \%)$ of the White farm studied are primary owners/ operators, while 37\% (47) are secondary owners/operators. On the other hand, Farmers of Color are more likely to be secondary than primary farm owners/operators. Ten of the $17(58.8 \%)$ Farmers of Color are primary owners/operators, and seven $(41.2 \%)$ are secondary owners/operators.

Males comprise $54.2 \%$ (78) of all the owners/operators. However, they are more likely to be primary owners/ operators than secondary ones. Hence, $61.1 \%$ (55) of the primary owners/operators are male. In contrast, females account for $57.4 \%$ (31) of the secondary farm owners/ operators.

Most farmers work on the farm full time; $59 \%$ (85) do. Moreover, $70 \%$ (63) of the primary owners/operators are full-time employees of their farm. Only $40.7 \%$ (22) of the secondary owners/operators work on their farms full time. The data show that $30 \%$ (27) of the primary owners/operators and $51.9 \%$ (28) of the secondary owners/operators work on the farms part-time. Only four farm owners/operators do not work on the farm, and all are secondary owners/ operators.
The mean age for the farm owners/operators is 53.9 years. The primary owners/operators are slightly younger than the secondary owners/operators. While the mean age for the primary owners/operators is 53.4 years, it is $\mathbf{5 4 . 7}$ years for the secondary owners/operators. White farm owners/operators tend to be older than People of Color farm owners/operators. The mean age for the White owners/operators is 54.7 years and 48 years for People of Color owners/operators. The biggest age gap is apparent between White primary owners/ operators and People of Color owners/operators. On average, White primary farm owners/operators are about 12 years older than the primary People of Color farm operators/ owners. The People of Color who are primary farm owners/ operators also tend to be younger than secondary owners/ operators. While the mean age for People of Color primary farm owner/operator is 42.7 years, it is $\mathbf{5 5 . 6}$ years for secondary farm owners/operators.

Males who were primary farm owners/operators tended to be older than females who were primary owners/operators. The mean age for the male primary owner/operators was 55.3 years. The mean age of their female counterparts was 50.4 years. The opposite is true for secondary farm owners/operators. Female secondary owners/operators have a slightly higher mean age than males who are secondary owners/operators of farms. While males who are primary owners/operators are 2.1 years older than the males who are secondary owners/operators, the age difference amongst the female primary and secondary owners/operators is larger. The mean age of female primary farm owners/operators is 
Table 2 The relationship between farm characteristics and the race/ethnicity of owners/operators

\begin{tabular}{|c|c|c|c|c|c|c|}
\hline \multirow[t]{2}{*}{ Characteristics } & \multicolumn{2}{|c|}{ Total sample } & \multicolumn{2}{|l|}{ White } & \multicolumn{2}{|c|}{ People of Color } \\
\hline & Number & Percent & Number & Percent & Number & Percent \\
\hline \multicolumn{7}{|l|}{ Size of farm } \\
\hline 1-19 Acres & 37 & 41.1 & 24 & 32.0 & 13 & 86.7 \\
\hline 20-99 Acres & 29 & 32.2 & 28 & 37.3 & 1 & 6.7 \\
\hline 100 Acres or More & 24 & 26.7 & 23 & 30.7 & 1 & 6.7 \\
\hline \multicolumn{7}{|l|}{ Number of owners/operators } \\
\hline One & 36 & 40.0 & 28 & 37.3 & 8 & 53.3 \\
\hline Two & 54 & 60.0 & 47 & 62.7 & 7 & 46.7 \\
\hline \multicolumn{7}{|l|}{ Number of full or part-time workers } \\
\hline None, no answer & 36 & 40.0 & 31 & 41.3 & 5 & 33.3 \\
\hline $1-9$ & 34 & 37.8 & 26 & 34.7 & 8 & 53.3 \\
\hline 10 or more & 20 & 22.2 & 18 & 24.0 & 2 & 13.3 \\
\hline \multicolumn{7}{|l|}{ Ownership of the farm } \\
\hline Operator owns all of the farm & 54 & 60.0 & 44 & 58.7 & 10 & 66.7 \\
\hline Operator rents, leases, or other & 36 & 40.0 & 31 & 41.3 & 5 & 33.3 \\
\hline \multicolumn{7}{|l|}{ Arrangements for some/all of the farm } \\
\hline \multicolumn{7}{|l|}{ Organic or conventional } \\
\hline Certified organic & 13 & 14.4 & 12 & 16.0 & 1 & 6.7 \\
\hline Uses organic practices but not certified organic & 48 & 53.3 & 35 & 46.7 & 13 & 86.7 \\
\hline Some certified organic and some not certified organic & 4 & 4.4 & 3 & 4.0 & 1 & 6.7 \\
\hline Conventional; not organic & 25 & 27.8 & 25 & 33.3 & 0 & 0.0 \\
\hline \multicolumn{7}{|l|}{ Length of time operating the farm } \\
\hline $1-9$ years & 23 & 27.4 & 16 & 22.9 & 7 & 50.0 \\
\hline $10-19$ years & 31 & 36.9 & 26 & 27.1 & 5 & 35.7 \\
\hline 20 or more years & 30 & 35.7 & 28 & 40.0 & 2 & 14.3 \\
\hline
\end{tabular}

50.4 years. The females who are secondary farm owners/ operators are, on average, 4.3 years older; their mean age is 54.7 years.

\section{Farm characteristics and the race/ethnicity of owners and operators}

White farmers tend to operate larger farms than People of Color owners/operators. The most common farms in our study are less than 20 acres; $41.1 \%$ (37) of the farms are 1-19 acres in size (Table 2). Almost a third (29) of the farms are 20-99 acres in size, and $26.7 \%$ (24) of the farms studied are 100 acres or larger. Most People of Color owners have farms that are less than 20 acres in size; that is, $86.7 \%$ (13) of People of Color owners/operators oversee farms that are 1-19 acres. In comparison, 32\% (24) of Whites operate similarly sized farms. That is, 51 (68\%) of Whites operate farms that are 20 acres or more. While the mean farm size of White owners/operators was 62 acres, it was 12.1 acres for People of Color owners/operators.

Typically, two owners/operators oversee the farm- $60 \%$ (54) of the farms have a primary and a secondary owner/ operator. However, there are striking differences between
White-owned/operated farms and those owned/operated by People of Color. Two farmers (primary and secondary) oversee almost $63 \%$ (54) of the White-owned/operated farms. In contrast, only $46.7 \%$ (seven) of the People of Color farms have two farmers overseeing the operations.

The farms usually have a small workforce. Forty percent (36) of the farms have no workers or did not answer the question, while $34(37.8 \%)$ have between one and nine workers. Twenty farms (22.2\%) had ten or more employees. White-owned/operated farms tend to have a larger workforce than those operated by People of Color. While 24\% (18) of White-run farms have ten or more workers, only two (13.3\%) People of Color owned/operated farms have as many workers.

There is a high rate of ownership of the farms studied. The current operators owned $60 \%$ of the farms. Only $40 \%$ (36) of the operators rented, leased, or had other financial arrangements with their farms. About 59\% (44) of White farmers and two-thirds (ten) of People of Color farmers own the farms they operate.

Most of the farms studied used organic practices. Only $27.8 \%$ or 25 farms were wholly conventional. Most farms (53.3\% or 48 ) used organic methods, but they did not have 
organic certification. That is, they did use organic techniques on the farms. However, $13(14.4 \%)$ of the farms in our study were certified organic. Another $4.4 \%$ (four) had mixed organic practices; the farmers used organic methods on the whole farm, but only some of their products had an organic certification.

Most People of Color (86.7\% or 13) operate farms that use organic practices, but they do not have organic certification. In comparison, $46.7 \%$ (35) of White farmers use organic farming practices, but they do not have organic certification. More specifically, 16\% (12) of White farmers have a farm with organic certification, so do $6.7 \%$ (one) of Farmers of Color own or operate such farms. Though a third (25) of White farmers owned/operated conventional farms, no People of Color owned or operated conventional farms.

The farms were usually well established. While 23 (27.4\%) of the owners operated their farms for less than a decade, $61(72.6 \%)$ operated for ten or more years. Thirty of the owners (35.7\%) worked their farms for 20 or more years. However, People of Color have much shorter tenure on their farms than White farmers. Seven (50\%) of the People of Color farmers operated their farms for 1-9 years; 16 (22.9\%) of the White farmers operated for less than ten years.

\section{Farm financing and racial/ethnic characteristics of owners/operators}

Most farmers indicate they have not taken out any loans to finance their farms; 46 out of 73 (63\%) of the farmers who answered this question have not taken out farm loans. However, 37\% (27) of the farmers have taken out loans (Table 3). The data show that more farmers seek loans than succeed in taking out loans for their farms. While 27 (37\%) farmers have taken out farm loans, 40 (69\%) said they tried to obtain loans in the past decade. More specifically, 25 (43.1\%) of the farmers tried to take out one to three loans, and another $15(25.9 \%)$ tried to get between four and ten loans for their farms.

Twenty-three (37.1\%) Whites four (36.4\%) People of Color took out loans to finance their farms. However, five of the nine (55.6\%) People of Color farmers answering this question reported difficulty obtaining loans. Nineteen of 51 (37.2\%) White farm owners/operators who responded to this question also said they had difficulties obtaining loans for their farms.

Farmers are most likely to seek financing from the FSA, an arm of the USDA. Twenty-one (31.3\%) farmers sought FSA loans, and 15 succeeded in getting them. All the farmers who got FSA loans were White. So, 15 of the 18 or $83.3 \%$ of White farmers who applied for FSA loans succeeded in getting the loans. In contrast, none of the three People of Color farmers who applied for FSA loans got them.
People of Color farmers were more successful in obtaining credit union loans; four of the six (66.7\%) People of Color farmers who applied for credit union loans obtained them. The two Farmers of Color who applied for bank loans also got them. In comparison, three of the six (50\%) White farmers who sought credit union loans got them, and 11 of the 16 (68.8\%) who applied for bank loans succeeded in getting them.

While four White farmers obtained loans from cooperatives, no Farmer of Color sought loans from this type of institution. Farmers also turned to other sources for loans; they sought and got loans from family, friends, private investors, and the Farm Credit Services of America.

Farmers also reported specific challenges they faced while seeking financing. Sixteen farmers-13 White and three People of Color-said they did not borrow any money to finance their farms. Another 11 farmers reported not encountering any difficulties when seeking loans. However, most farmers who borrowed money said they faced challenges when seeking financing for their farms. Table 4 summarizes the themes that arose when farmers described their experiences during the financing process.

For instance, four White farm owners/operators and one Person of Color operator said that the FSA was not a farmer-friendly loan system. Other farmers noted that the terms of the loans were unattractive and that the interest rates were too high for them to afford. Five farmers indicated that they paid rates as high as $10 \%$. Three other farmers paid 7\% interest, while five paid 6\%. Twenty-three farmers had loans with interest rates between 2 and 5\%.

\section{Availability of funding during the pandemic}

Farmers identified where they obtained financial assistance during the pandemic. White farm owners/operators accessed a more comprehensive range of financial assistance programs than Farm Owners/Operators of Color. Hence, White farm owners/operators reported that they accessed 15 sources of financial assistance while People of Color farm owners/operators reported receiving financial assistance from only three sources (Table 5). Thus, none of the People of Color farm owners/operators obtained paycheck-protection program (PPP) loans. People of Color farm owners/operators did not receive any CFAP-1 loans either. However, one of the seven CFAP-2 loans went to a Person of Color farm owner/operator. Four Farmers of Color received stimulus checks and one received unemployment benefits. Neither the stimulus checks program nor unemployment benefits are explicitly targeted to farmers per se; they are assistance geared towards the general population. 


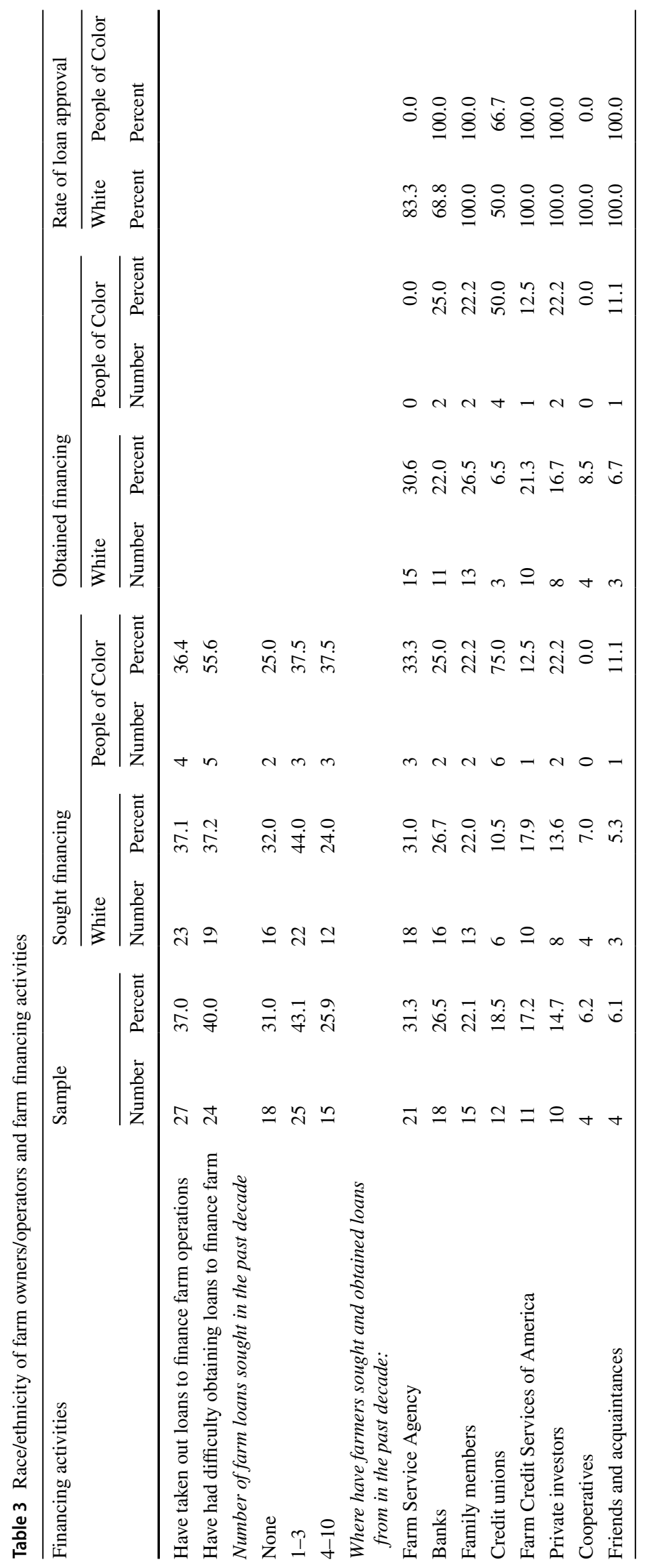


Table 4 Race/ethnicity of farm owners/operators and challenges obtaining loans

\begin{tabular}{|c|c|c|c|}
\hline Factors identified & Total & $\begin{array}{l}\text { White owners/opera- } \\
\text { tors }\end{array}$ & $\begin{array}{l}\text { People of Color } \\
\text { owners/opera- } \\
\text { tors }\end{array}$ \\
\hline Do not borrow or try not to borrow & 16 & 13 & 3 \\
\hline None, not applicable & 11 & 9 & 2 \\
\hline Difficulty with the Farm Service Agency—not farmer friendly loan system & 5 & 4 & 1 \\
\hline High debt to equity ratio a hindrance, not enough income to secure loan & 4 & 3 & 1 \\
\hline Low credit score & 3 & 2 & 1 \\
\hline Commercial loans with very unattractive terms are offered & 2 & 2 & \\
\hline Charged interest rates that are too high & 2 & 2 & \\
\hline Uncertainty of the future of farming & 2 & 2 & \\
\hline Large amount of paperwork & 2 & 2 & \\
\hline Do not own enough land, too small & 2 & 2 & \\
\hline Options are limited & 1 & 1 & \\
\hline Farms are not recognized by conventional lenders & 1 & 1 & \\
\hline Difficult to get loans or qualify for loans & 1 & 1 & \\
\hline Large amount of equipment or land asked for as collateral & 1 & 1 & \\
\hline Farm improvements delayed because of difficulty getting loans & 1 & 1 & \\
\hline Financial institutions are reluctant to lend operating capital & 1 & 1 & \\
\hline Have to take out personal loans to finance business & 1 & 1 & \\
\hline Making accurate predictions of costs for the business plan & 1 & 1 & \\
\hline Don't know the system & 1 & 1 & \\
\hline Grants are better than loans & 1 & & 1 \\
\hline Personal loans are better than bank loans & 1 & & 1 \\
\hline Tried to refinance mortgage but was unsuccessful & 1 & & 1 \\
\hline Have to have off-farm job to have enough income to qualify for loan & 1 & & 1 \\
\hline Profitability during COVID is difficult & 1 & 1 & \\
\hline Assets are undervalued & 1 & 1 & \\
\hline Not yet making a profit & 1 & 1 & \\
\hline Organizations do not want to help & 1 & & 1 \\
\hline It takes too long to process loans & 1 & 1 & \\
\hline Too new to obtain a loan & 1 & 1 & \\
\hline The credit union does not lend for agricultural purposes & 1 & 1 & \\
\hline Did not have collateral necessary to secure loans & 1 & 1 & \\
\hline Take family loans instead & 1 & 1 & \\
\hline
\end{tabular}

\section{Response to government assistance}

Study participants indicated how they felt about the government's efforts to assist farmers. A total of 61 farm owners/operators stated how they felt about the government's response to the pandemic (Table 6). While $25(41 \%)$ were critical of government responses, 18 (29.5\%) of the farmers were supportive of what the government had done to respond to the pandemic, and $13(21.3 \%)$ were ambivalent. Eighteen out of $50(36 \%)$ White farm owners/operators were critical of the government responses, so were seven of eleven (63.6\%) People of Color farm owners/operators responding to the question. Though none of the Farm Owners/Operators of Color supported the government responses, 18 (36\%) White farm owners/operators expressed approval.

\section{Criticism of government responses}

Fifty-six respondents wrote detailed comments about government responses to the pandemic. Twenty-five respondents wrote critical comments. The criticisms fell into two thematic areas: the belief that the government favored large farmers over small ones in assistance programs and the feeling that the response was slow and cumbersome. The following discussion uses quotes from farmers' open-ended responses to illustrate each theme identified. 
Table 5 Race/ethnicity of farm owners/operators and financial assistance during the COVID19 pandemic

\begin{tabular}{llll}
\hline Source of funding & Total & $\begin{array}{l}\text { White owners/ } \\
\text { operators }\end{array}$ & $\begin{array}{l}\text { People of Color } \\
\text { owners/opera- } \\
\text { tors }\end{array}$ \\
\hline None & 28 & 22 & 6 \\
Paycheck Protection Program (PPP) loans & 11 & 11 & \\
Coronavirus Food Assistance Program 1 (CFAP) & 10 & 10 & 1 \\
Coronavirus Food Assistance Program 2 (CFAP) & 7 & 6 & 4 \\
Federal government stimulus check & 7 & 3 & \\
Personal Protective Equipment (PPE) loans & 4 & 4 & 1 \\
U.S. Department of Agriculture funding & 2 & 2 & \\
Economic Injury Disaster Loans (EIDL) & 2 & 2 & \\
Small Business Administration loan & 2 & 2 & \\
Unemployment benefits & 2 & 1 & \\
Food Assistance Lunch Box Program & 1 & 1 & \\
Small grants & 1 & 1 & \\
Private foundation grant & 1 & 1 & \\
Grain subsidies & 1 & 1 & \\
Chamber of Commerce gift & 1 & 1 & \\
Michigan Economic Development Corporation (MEDC) & 1 & 1 & \\
\hline
\end{tabular}

Table 6 Race/ethnicity of farm owners/operators and perceptions of government responses to the COVID-19 pandemic

\begin{tabular}{|c|c|c|c|c|c|c|}
\hline \multirow[t]{2}{*}{$\begin{array}{l}\text { Perceptions of government responses to } \\
\text { the pandemic }\end{array}$} & \multicolumn{2}{|c|}{ Total $(n=61)$} & \multicolumn{2}{|c|}{$\begin{array}{l}\text { White owners/ } \\
\text { operators }(n=50)\end{array}$} & \multicolumn{2}{|c|}{$\begin{array}{l}\text { People of Color } \\
\text { owners/operators } \\
(n=11)\end{array}$} \\
\hline & Number & Percent & Number & Percent & Number & Percent \\
\hline Critical of government responses & 25 & 41.0 & 18 & 36.0 & 7 & 63.6 \\
\hline Ambivalent about government responses & 13 & 21.3 & 11 & 22.0 & 2 & 18.2 \\
\hline Supportive of government responses & 18 & 29.5 & 18 & 36.0 & 0 & 0.0 \\
\hline Don't know about government responses & 5 & 8.2 & 3 & 6.0 & 2 & 18.2 \\
\hline
\end{tabular}

Favoring large farmers over small farmers Favoritism was a point of contention for some study participants who criticized government responses during the pandemic. A White female farmer from Southwest Michigan said of the government, "Well, they help large farmers who export, but for small farmers like us, we don't believe they've done anything." The small farmers were troubled by what they saw as efforts made to help large producers while ignoring small producers.

A White farmer from the Upper Peninsula of Michigan echoed this theme in his comments. He noted that "CARES [Coronavirus Aid, Relief, and Economic Stability Act] funding did not help the small farmer [and] most of it went to larger farms." Additionally, another said, "I think it's far past due that the government actively supports small farms." A farmer also said, "I think farmers, like many small businesses (especially restaurants), are being left behind."

Farmers thought that the distribution of CFAP-1 was unfair. It is evident in statements like, "CFAP was a handout for larger farmers votes." A Farmer of Color from Southeast
Michigan reported that after small farmers saw how CFAP-1 was disbursed, they organized, expressed their concerns, and advocated for change. The farmer noted,

The first ag[riculture] COVID relief package [CFAP1] didn't apply to us, which was extremely frustrating. They did fix most the issues that farmers like [me] brought up.

A White organic farmer from Southeast Michigan also criticized the emergency assistance to large farmers because he felt that CFAP ignored small farmers using sustainable practices. The farmer said,

They are creating an unfair advantage to those that are getting the funding and hurting other farmers who... don't qualify for the funding... The government subsidies and [is] financing unsustainable farming operations that would not be able to support themselves without it...Farms like mine who are producing organic and sustainable products have to compete for 
resources (farmland, equipment, etc.) with farms that are getting government funding, and it gives them an unfair advantage that they wouldn't have on a free market.

Some farmers see the lack of consideration of small farmers in the early round of aid assistance as a sign of disrespect. Reflecting on this, a White female farm owner/operator from Central Michigan said,

...Small farmers are not respect[ed] through the USDA or MDARD [the Michigan Department of Agriculture \& Rural Development]. We are known as 'freaks' before the pandemic, so what do you think they think of us now.

Others pointed to the back-and-forth between the state and the federal governments as problematic. According to a White male owner/operator from the Southeast portion of the state, the "state of Michigan didn't do much for farmers, but it is not their job, the federal government did a very poor job." Farmers were also frustrated by the stalemate between the Republicans and Democrats. As one White female owner/operator from the Southwestern part of Michigan saw it,

...they did the first (CARES Act) but have been arguing between the parties (GOP [Republicans] and DEM [Democrats]) ever since while people remain unemployed, going through savings, etc. That makes it difficult for them [the customers] to make higher purchases at farmers markets etc.

Slow and inadequate government response Study participants also mentioned the speed of the response and the clarity of the guidelines under which they and farmer's markets could operate. A White female farm owner/operator from Southwest Michigan said the response was "slow, very hard to navigate, focused on large commodity producers, uninformed and unfocused." A female Farm Owner/Operator of Color from South Central Michigan commented on the federal and state response. She felt the government's response was,

Very poor. Our local health dep[artmen]t and the state are doing the best they can, but the Federal response is lousy.

While one farmer said the response was "terrible for $\mathrm{a}[\mathrm{n}]$ owner/operator of a small farm," another said,

I wish they would have been a lot quicker setting out specific guidelines for how farmer's markets should operate when the pandemic first started. There was a lot of confusion and inconsistency across markets in practices; some stayed open, some closed, and there was no cohesive strategy for making a market safe. This affected us [because] it is our main place of sales.

A White female respondent from Central Michigan thought that the government was unprepared to address the crisis. She notes,

I think the response, in general, was woefully inadequate, but especially for small farmers. The CFAP-2 assistance made it easier for small farmers to get some relief. Overall, though, it was clear that the government had not fully prepared for how to address such a crisis.

Another White female study participant from Central Michigan who said the government's response was "bad" explained that,

The government's response has been a through-line of disappointment and death...we needed leadership. Farmers are resilient people who didn't expect or receive special assistance.

\section{Ambivalence}

Thirteen farmers were non-judgmental about or did not react to the government's financial assistance to farmers. Others saw both negatives and positives in government responses. Statements like this, which came from a White female farm owner/operator in the Upper Peninsula, exemplify the ambivalence.

The government did what it could, but dairy is a specialty product. We cannot sell it anywhere but thru the coop to a Grade A processor, so our hands are tied on price and markets.

The following statement by a White Upper Peninsula farm owner/operator is also ambivalent. He thought the government's assistance was,

Probably overly generous. Glad to see that [the government] spread the help around to more than just the corn, soybean, and cotton farmers.

Another farm owner/operator-a White female from Central Michigan - questioned the necessity of government assistance and who received aid in this statement,

It [the assistance] was great but, likely unnecessary. BIPOC [Black, Indigenous, and People of Color] and LGBTQ [lesbian, gay, bisexual, transgender, and queer] farmers deserve more support but, the broad strokes of the loan program were probably not necessary. If those with the most opportunity and generational wealth cannot survive through this and adapt, I 
do not feel sorry for them, nor should they have been given grants.

\section{Praise for the government's handling of assistance to farmers}

Eighteen farmers were supportive of the government's pandemic responses. They used phrases like "great" and "excellent" to praise the government. A White male farmer from Southwest Michigan said, "The COVID grant to our farm made a substantial difference." A White female farm owner/operator from the Northwest portion of the Lower Peninsula said, "It has been good. The programs we applied for had simple applications and quick responses." Others reported that the assistance was "very helpful" and "better than expected. We are thankful for anything we received." A White female Southeast Michigan farm owner/operator also said,

We are very much proponents of the CFAP payments to farmers as well as funding for food distribution to food banks.

Another White female study participant from the Upper Peninsula reiterated this point by saying that “ $\ldots$... allowing farmers to participate in food banks and other forms of food assistance was a great idea." A White male respondent from Southwest Michigan who thought that government officials "were fairly responsive" also said that such officials "tried to make the process fairly easy. I appreciate[d] the help." One farmer-a White male from the Northwest part of the Lower Peninsula — concluded by saying, "So far so good, it [the government assistance] has kept us in business."

\section{Impacts of the pandemic on farming operations}

\section{Farming and sales}

The pandemic impacted the farmers studied in many ways in 2020. Seventy-one farmers answered the question about the start of the growing season. Forty-nine (69\%) of them said they started farming at the same time as usual in 2020. However, 16 (22.5\%) indicate that they had to delay their farming activities because of COVID-19. Hence, 11 of 60 (18.3\%) White farmers and 5 of 11 (45.5\%) People of Color farmers started their farming activities later than usual. Six or $8.5 \%$ of the farmers started farming activities earlier than usual. Though our study inquired only about the impacts of COVID-19 on the start of farming activities for the year, other factors such as unseasonably cold weather, flooding, lack of workers, and financial troubles can also cause delays.

As Table 7 shows, 79.3\% (46) of White farm owners/ operators and all the People of Color farm owners/operators said they farmed the same number of acres as they did the previous year. However, 19 farm owners/operators (15 White and four People of Color) said they had fewer farmers' markets to sell their products. In other words, $28.8 \%$ of White farm owners/operators and $44.4 \%$ of Farmers of Color found this to be the case.

The urban or rural location of the farmers market might influence if or when it opened during the pandemic. Sixteen $(17.8 \%)$ of the 90 farms studied were in urban areas, and seven $(9.3 \%)$ of the 75 White farmers operated farms in urban areas. In comparison, $9(60.0 \%)$ of the 15 People of Color farmers operated farms in cities. Most of the urban farms included in this study were in the southern part of the state. The pandemic ravaged Southeastern Michigan first, then slowly spread northwards and westwards during the late summer. Therefore, it is likely that the pandemic could have caused farmer's markets in Southern Michigan to close.

When restaurants and other institutions closed, it also reduced the number of venues the farmers studied could sell their products. A higher percentage of White farm owners/operators reported not selling to restaurants and other institutions than People of Color farm owners/operators. Twenty-two (48.9\%) White farm owners/operators said they sold to fewer restaurants because of the pandemic. In comparison, three (33.3\%) People of Color farm owners/ operators reported that their sales to restaurants declined. White farmers were also more likely than Farmers of Color to report that the number of other institutions they sold products to decreased; 17 (36.2\%) of White farmers and none of the Farmers of Color said this was the case.

In 2020, most White farm operators hired roughly the same number of workers they had in 2019 and mobilized roughly the same volunteers. However, this was not the same for Farmers of Color. Twenty-nine (54.7\%) of 53 White farm owners/operators hired roughly the same number of workers as the previous year. However, only two (22.2\%) of nine Farmers of Color hired the same number of workers. Five (55.6\%) of the Farmers of Color said they hired fewer workers than the previous year. Farmers of Color also reported that the number of volunteers who helped on their farms shrunk in 2020; seven of eleven, or $63.6 \%$, said this was the case.

Farmers in our sample reported an increase in some of their farming, marketing, and sales activities. For instance, $16(35 \%)$ White farmers and one (12.5\%) Farmers of Color increased their community-supported agriculture (CSA) activities. Farmers also reported that they had more customers in 2020 than in 2019. White farmers were more likely to report increased customers than Farmers of Color. Hence, 33 (57.9\%) White farmers and three (33.3\%) Farmers of Color said more customers purchased items from them in 2020. Overall, 35.4\% (23) of the farmers studied reported that the revenues generated from the farm increased in 2020. Farmers also saw an increase in the number of people seeking 


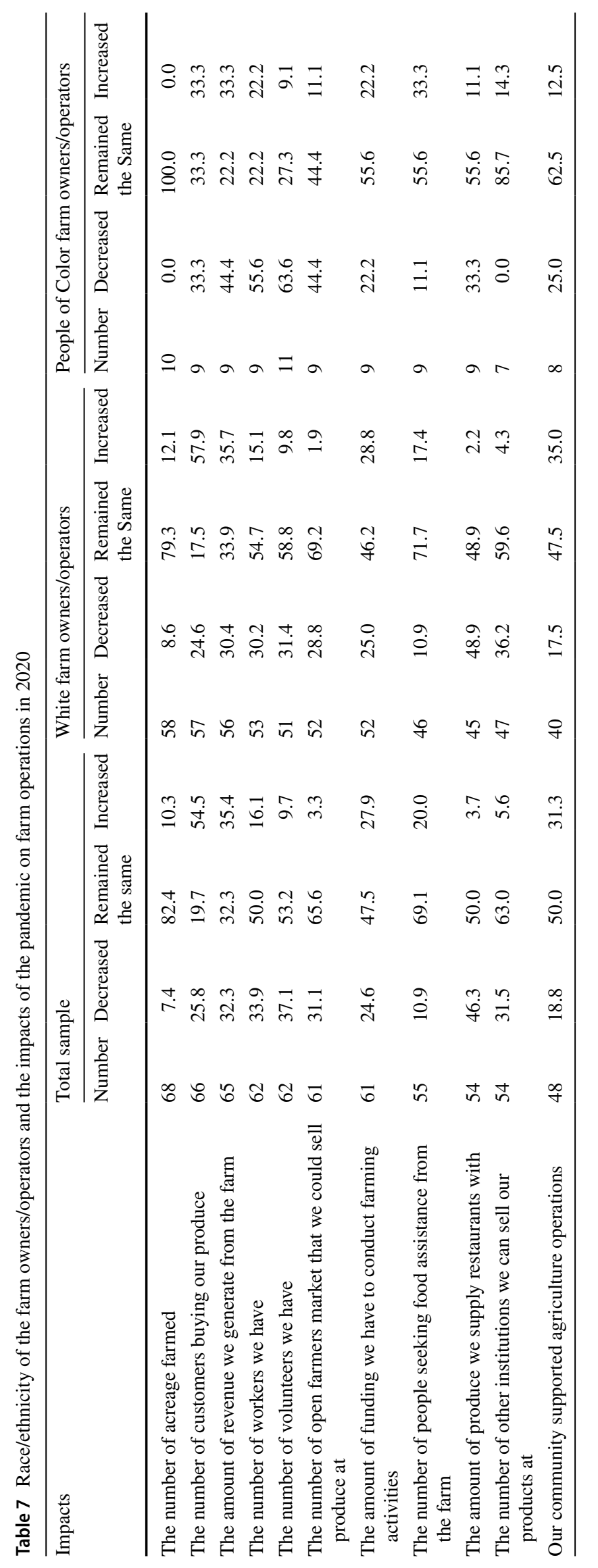


Table 8 Race/ethnicity of owners/operators and what happens to unsold farm products

\begin{tabular}{|c|c|c|c|c|c|c|}
\hline \multirow[t]{2}{*}{ Fate of unsold farm products } & \multicolumn{2}{|c|}{ Total sample } & \multicolumn{2}{|l|}{ White } & \multicolumn{2}{|c|}{ People of Color } \\
\hline & Number & Percent & Number & Percent & Number & Percent \\
\hline Give them away to friends, family, or neighbors & 57 & 82.6 & 46 & 79.3 & 11 & 100.0 \\
\hline Compost them & 45 & 65.2 & 35 & 60.3 & 10 & 90.9 \\
\hline Feed them to farm animals & 42 & 59.2 & 36 & 60.0 & 6 & 54.5 \\
\hline Sell them at reduced prices & 37 & 52.9 & 31 & 52.5 & 6 & 54.5 \\
\hline Give them away to anyone who asks & 37 & 52.9 & 27 & 45.8 & 10 & 90.9 \\
\hline Preserve them & 36 & 51.4 & 31 & 52.5 & 5 & 45.5 \\
\hline Invite people to glean it & 34 & 48.6 & 25 & 42.4 & 9 & 81.8 \\
\hline Plough it back into the fields for fertilizer & 33 & 47.1 & 26 & 44.1 & 7 & 63.6 \\
\hline Donate them to food pantries & 32 & 47.1 & 27 & 47.4 & 5 & 45.5 \\
\hline Donate them to soup kitchens & 20 & 29.0 & 15 & 25.9 & 5 & 45.5 \\
\hline Donate them to food aggregators & 20 & 28.6 & 17 & 28.8 & 3 & 27.3 \\
\hline Throw them away, dispose of them & 20 & 28.6 & 18 & 30.5 & 2 & 18.2 \\
\hline Donate them to shelters & 15 & 22.4 & 12 & 21.4 & 3 & 27.3 \\
\hline Donate them to churches/religious institutions & 15 & 21.7 & 11 & 19.0 & 4 & 36.4 \\
\hline Donate them to schools & 12 & 17.4 & 9 & 15.5 & 3 & 27.3 \\
\hline
\end{tabular}

food assistance from their farms; this was particularly true at farms operated by People of Color. Thus, 17.4\% (8) of White owners/operators and a third (3) of the People of Color owners/operators reported increased requests for food assistance.

\section{The fate of unsold products}

Food insecurity increased dramatically because of the pandemic, and farmers are critical actors to meet the demand for emergency food (Benton 2020; Dickinson 2020; Emmad and Peña 2020). Consequently, we asked farmers to say what they did with produce and other perishable items that they did not sell. Farmers frequently gave away unsold products to their friends, family, or neighbors; $82.6 \%$ (57) did this. All eleven Farm Owners/Operators of Color and 46 (79.3\%) White farm owners/operators gave food to family, friends, or neighbors (Table 8 ).

Twenty-seven (45.8\%) of 59 White farm owners/operators said they gave away unsold food or perishable products from the farm to anyone who asks. Ten (90.9\%) of eleven Farmers of Color did the same. Similarly, for gleaning, nine $(81.8 \%)$ of the Farmers of Color said they invited people to glean their farms. In comparison, 25 (42.4\%) White farm owners/ operators invited people to glean on their farms.

Thirty-seven $(52.9 \%)$ of the farmers said they reduced the price of products to sell them. Some of the study participants preserved unsold food while others threw it away. While 36 $(51.4 \%)$ of the respondents said they preserved unsold food, $20(28.6 \%)$ reported throwing such food away. Thirty-two farmers $(47.1 \%)$ donated unsold products to food pantries. A smaller number, 20 (28.6\%), donated unsold products to soup kitchens and food aggregators.

\section{Other responses to the pandemic}

During the pandemic, farm owners/operators made a variety of changes in the way they operated their farms or conducted their business. Table 9 contains the most common themes that emerged in the farmers' responses to the pandemic. The most frequently reported response to COVID-19 was to institute social distancing practices on their farms, at their farm stores and stands, or when they sold products at farmer's markets. Ten farmers reported they instituted social distancing practices, while another seven required customers to wear masks in their stores or on their farms. Five farmers focused on enhancing sanitation at their farms, while four installed handwashing and sanitizing stations. Farmers also said they communicated clearly with customers about safe practices on their farms, and they installed plastic shields to separate customers from cashiers and other employees.

Eight farmers (seven White and one Person of Color) moved some of their business online. Consequently, they expanded their sales by selling during the summer and yearround. Farmers also devised alternative forms of contactless deliveries to customers. Hence, four farmers made home deliveries, three allowed customers to pick up purchases at local farmer's markets, and another three allowed customers to pick up purchases at the farms.

Farmers identified several challenges with obtaining chickens and other livestock they wanted to grow. Some said they had difficulty finding places to slaughter and process animals after the meat-processing facilities they were accustomed to using shuttered temporarily.

Farmers also said they had difficulty finding enough seeds or plants to purchase. It was the case because many more people started home gardens and grew their fruits 
Table 9 Race/ethnicity of farm owners/operators and responses to the COVID-19 pandemic

\begin{tabular}{|c|c|c|c|c|c|c|c|}
\hline Responses & Total & $\begin{array}{l}\text { White own- } \\
\text { ers/opera- } \\
\text { tors }\end{array}$ & $\begin{array}{l}\text { People of Color } \\
\text { owners/opera- } \\
\text { tors }\end{array}$ & Responses & Total & $\begin{array}{l}\text { White own- } \\
\text { ers/opera- } \\
\text { tors }\end{array}$ & $\begin{array}{l}\text { People of Color } \\
\text { owners/opera- } \\
\text { tors }\end{array}$ \\
\hline $\begin{array}{l}\text { Practice social distancing; post } \\
\text { social distancing instructions }\end{array}$ & 10 & 8 & 2 & $\begin{array}{l}\text { Hired more employees to } \\
\text { handle increased sales }\end{array}$ & 1 & 1 & \\
\hline $\begin{array}{l}\text { Added online storefront-as } \\
\text { summer and year-round } \\
\text { operation }\end{array}$ & 8 & 7 & 1 & $\begin{array}{l}\text { Reconfigured customer traffic } \\
\text { flow at the farm }\end{array}$ & 1 & 1 & \\
\hline $\begin{array}{l}\text { Customers and staff have to } \\
\text { wear masks in on-farm store, } \\
\text { at the farm }\end{array}$ & 7 & 6 & 1 & No touching of products & 1 & 1 & \\
\hline $\begin{array}{l}\text { Nothing new-business as } \\
\text { usual }\end{array}$ & 6 & 5 & 1 & $\begin{array}{l}\text { Decrease food offerings from } \\
\text { the kitchen }\end{array}$ & 1 & 1 & \\
\hline $\begin{array}{l}\text { Increased focus on sanitation at } \\
\text { the farm }\end{array}$ & 5 & 3 & 2 & No hay rides or pony rides & 1 & 1 & \\
\hline $\begin{array}{l}\text { Stop or reduce selling at } \\
\text { farmer's markets }\end{array}$ & 4 & 4 & & $\begin{array}{l}\text { Still keeping the focus on } \\
\text { direct selling }\end{array}$ & 1 & 1 & \\
\hline $\begin{array}{l}\text { Make home deliveries of } \\
\text { orders-contactless }\end{array}$ & 4 & 4 & & $\begin{array}{l}\text { Donating more products from } \\
\text { the farm }\end{array}$ & 1 & 1 & \\
\hline $\begin{array}{l}\text { Install hand-washing and sani- } \\
\text { tizing station for customers }\end{array}$ & 4 & 3 & 1 & $\begin{array}{l}\text { Limit the number of customers } \\
\text { on the farm }\end{array}$ & 1 & 1 & \\
\hline $\begin{array}{l}\text { Trying to adjust to loss of } \\
\text { customers }\end{array}$ & 4 & 4 & & $\begin{array}{l}\text { Opened a self-served farm } \\
\text { stand at the farm }\end{array}$ & 1 & & 1 \\
\hline $\begin{array}{l}\text { Trying to keep up with and } \\
\text { adjust to the changing rules }\end{array}$ & 4 & 4 & & Increased operating capital & 1 & 1 & \\
\hline $\begin{array}{l}\text { Increase our community sup- } \\
\text { ported agriculture (CSA) } \\
\text { activities }\end{array}$ & 3 & 3 & & Reduced debt & 1 & 1 & \\
\hline $\begin{array}{l}\text { Pick up orders at local farmer's } \\
\text { markets—contactless }\end{array}$ & 3 & 3 & & Curtail educational activities & 1 & 1 & \\
\hline $\begin{array}{l}\text { Pick up orders at the farm- } \\
\text { contactless }\end{array}$ & 3 & 2 & 1 & Stop farm stays & 1 & 1 & \\
\hline $\begin{array}{l}\text { It is harder to process meat; } \\
\text { taking the animals to more } \\
\text { processors }\end{array}$ & 3 & 2 & 1 & Shift to growing microgreens & 1 & & 1 \\
\hline $\begin{array}{l}\text { Make reservation meat proces- } \\
\text { sors well in advance; few are } \\
\text { open }\end{array}$ & 3 & 2 & 1 & $\begin{array}{l}\text { Purchase equipment to start } \\
\text { growing indoors earlier }\end{array}$ & 1 & & 1 \\
\hline $\begin{array}{l}\text { Increased the size of the on- } \\
\text { farm, u-pick market }\end{array}$ & 3 & 2 & 1 & Streamlining water system & 1 & & 1 \\
\hline $\begin{array}{l}\text { Identifying ways to sell live- } \\
\text { stock; difficulty selling farm } \\
\text { animals }\end{array}$ & 3 & 3 & & Identifying new customer base & 1 & 1 & \\
\hline Increased sales & 3 & 3 & & $\begin{array}{l}\text { Shift to outdoor activities like } \\
\text { apple picking }\end{array}$ & 1 & 1 & \\
\hline $\begin{array}{l}\text { Stressed, going crazy, barely } \\
\text { coping }\end{array}$ & 2 & 2 & & Organize staff training & 1 & 1 & \\
\hline $\begin{array}{l}\text { Increased purchase of live- } \\
\text { stock, increased the sale of } \\
\text { meat }\end{array}$ & 2 & 2 & & $\begin{array}{l}\text { Make COVID testing available } \\
\text { to workers }\end{array}$ & 1 & 1 & \\
\hline $\begin{array}{l}\text { Plastic barriers between } \\
\text { customers and cashiers, } \\
\text { employees }\end{array}$ & 2 & 2 & & $\begin{array}{l}\text { Seeds and plants were limited } \\
\text { as more people grew gardens }\end{array}$ & 1 & 1 & \\
\hline $\begin{array}{l}\text { Communicate about safe prac- } \\
\text { tices at the farm }\end{array}$ & 2 & 1 & 1 & $\begin{array}{l}\text { Trying to find canning supplies } \\
\text { - there was a shortage }\end{array}$ & 1 & 1 & \\
\hline Lowering prices, having sales & 2 & 2 & & Shared seeds with neighbors & 1 & 1 & \\
\hline Hold a volunteer day & 2 & 1 & 1 & Froze extra products & 1 & 1 & \\
\hline
\end{tabular}


Table 9 (continued)

\begin{tabular}{|c|c|c|c|c|c|c|c|}
\hline Responses & Total & $\begin{array}{l}\text { White own- } \\
\text { ers/opera- } \\
\text { tors }\end{array}$ & $\begin{array}{l}\text { People of Color } \\
\text { owners/opera- } \\
\text { tors }\end{array}$ & Responses & Total & $\begin{array}{l}\text { White own- } \\
\text { ers/opera- } \\
\text { tors }\end{array}$ & $\begin{array}{l}\text { People of Color } \\
\text { owners/opera- } \\
\text { tors }\end{array}$ \\
\hline Trying to find farm workers & 2 & 2 & & Plant more & 1 & 1 & \\
\hline $\begin{array}{l}\text { Used distributor to sell prod- } \\
\text { ucts }\end{array}$ & 2 & 2 & & Build greenhouse & 1 & & 1 \\
\hline $\begin{array}{l}\text { Customers pick out and pur- } \\
\text { chase bags of pre-packaged } \\
\text { products }\end{array}$ & 1 & 1 & & Update and upkeep the farm & 1 & & 1 \\
\hline Institute new practices & 1 & 1 & & Did not hire any staff & 1 & 1 & \\
\hline $\begin{array}{l}\text { Re-organizing u-pick opera- } \\
\text { tions }\end{array}$ & 1 & 1 & & $\begin{array}{l}\text { Cut back on the amount } \\
\text { planted }\end{array}$ & 1 & 1 & \\
\hline $\begin{array}{l}\text { Making concerted attempts to } \\
\text { get chickens, farm animals to } \\
\text { grow/process }\end{array}$ & 1 & 1 & & $\begin{array}{l}\text { Sold nursery plants to home } \\
\text { gardeners }\end{array}$ & 1 & 1 & \\
\hline $\begin{array}{l}\text { Reducing costs by cutting } \\
\text { down on the number of milk- } \\
\text { ing animals }\end{array}$ & 1 & 1 & & Closed the farm & 1 & 1 & \\
\hline $\begin{array}{l}\text { Searching for and finding new } \\
\text { opportunities }\end{array}$ & 1 & 1 & & $\begin{array}{l}\text { Canceled farm tours and school } \\
\text { outings }\end{array}$ & 1 & 1 & \\
\hline Forgoing needed things & 1 & 1 & & Stop selling meat & 1 & & 1 \\
\hline $\begin{array}{l}\text { Trying to make new business } \\
\text { start-up (the farm) work }\end{array}$ & 1 & 1 & & $\begin{array}{l}\text { Reduced number of hours } \\
\text { everyone worked }\end{array}$ & 1 & & 1 \\
\hline $\begin{array}{l}\text { Increase in the number of } \\
\text { customers }\end{array}$ & 1 & 1 & & & & & \\
\hline
\end{tabular}

and vegetables. In response, one farmer began selling nursery plants to home gardeners. Home gardeners also canned and preserved more than usual in 2020. It meant that farmers could not find enough cans and other materials needed to can, bottle, and preserve their products. Unable to secure enough cans, one farmer froze excess products in the hopes of using them in the future.

Farmers were nimble and continually shifted their strategies to take advantage of new market opportunities. One Farmer of Color reported that their farm installed a greenhouse and shifted to growing microgreens to meet the increased demand for the product and extend their growing and sales season.

Farmers also reorganized the u-pick activities on their farms. One created a self-serve farm stand, while others prepared pre-packaged bags of products that customers could select for purchase. Farmers also instituted a notouch (the products) policy. One farmer reported stopping selling meat from their farm while another closed their farm. Some shifted to outdoor fruit-picking activities. Hence, some shifted to apple-picking or similar types of fruit picking that could utilize social distancing. Farmers also canceled educational and social activities, hayrides and pony rides, school tours, and farm stays.

\section{Discussion}

This article is one of the first to examine how COVID-19 impacted farmers and farming operations. It is also unique in that it examines how farm owners/operators' racial/ethnic characteristics influence farm finances, operations, and the impacts of the pandemic and its responses. The paper highlights crucial information about farmers that merit further scholarly inquiry.

Before COVID-19, the USDA found that farm sales declined (USDA 2019a, b, c, d, e). About a third of the study participants said that their revenues in 2020 were less than in 2019. Our data suggest that farm revenues might have declined further for some of the farmers in our study. Declining revenues is concerning as the farms owned/operated by People of Color might be vulnerable because they tend to be smaller and with precarious financing. We found that four of nine People of Color farm owners/operators reported a decline in revenues. Our findings are consistent with other studies, which find that Farmers of Color own/operate smaller farms than White farmers (Carlisle et al. 2019; Horst and Marion 2019; Taylor 2018).

The study also found that Farmers of Color had difficulty securing loans to enhance their farm operations and accessed 
a smaller pool of federal loan assistance programs during the pandemic than White farm owners/operators. Past studies found that USDA and the FSA have systematically discriminated against Black and other Farmers of Color for decades (Taylor 2018; Daniel 2013; Minkoff-Zern and Sloan 2017; Carlisle et al. 2019). Scholars also report that Black farmers in Michigan have difficulty obtaining loans from these sources (Tyler et al. 2014). None of the Farmers of Color in our study obtained an FSA loan.

Another concern arose as we found that government pandemic financial relief seemed to have bypassed some farm owners/operators in our study. While White farm owners/ operators reported obtaining CFAP-1, CFAP-2, and other types of government grants and loans during the pandemic, only one Person of Color owner/operator reported receiving CFAP. Except for the stimulus checks and unemployment benefits that went to the general population, Farmers of Color were unlikely to report receiving the other kinds of financial support that White farmers received.

Several scholars have identified farm financial insecurity as a critical area that should concern us. Our findings lend credence to the claims of researchers who argue that more than half of all farmers are at risk of financial insecurity (Key et al. 2019; Hoppe 2017; Carlisle et al. 2019). Some farmers take off-farm jobs to make ends meet and stave off financial insecurity (USDA 2019d; Carlisle et al. 2019; Montri et al. 2021). We found evidence of this in our study. People of Color farmers are at increased risk of financial insecurity because their farms are small, have been operating for a short time, have declining sales, have young and inexperienced owners/operators, and have difficulty obtaining credit. Our findings suggest that we should pay more attention to Farm Owners/Operators of Color.

Farms owned/operated by People of Color might also be financially vulnerable for additional reasons. People of Color farms tend to have one owner/operator; more than half of their farms have one operator. It is in stark contrast to White-owned/operated farms - most of these have two owners/operators. The Farmers of Color in our study also own/operate farms that have fewer employees and volunteers than White-owned/operated farms. The size of the workforce has implications for expansion, adjusting to market changes like those brought on by COVID-19, and long-term viability. COVID-19 required farmers to assign more workers to make deliveries, shop for and pack customers' orders, monitor customers to see that they follow social distancing rules, and process online orders.

Blay-Palmar et al. (2020) predict that farmers will start or expand their online sales in response to COVID-19, and our findings support this claim. However, the online market might be bypassing Farmers of Color; only one Farmer of Color reported selling their farm's products online. Farmers who did not have the workforce to execute online-only or hybrid sales (online and in-person) were disadvantaged.

The FFFBP (Agricultural Marketing Service 2021; Galloway 2020; Sielski 2020) was popular with our study participants. The program provided a mechanism for farmers, who decided how much to grow before restaurants and other institutions they usually sold products to closed, to get their products to consumers. Through the program, farmers supplied soup kitchens, food banks, religious institutions, and other emergency food assistance nonprofits with produce to distribute to those seeking emergency food.

The FFFBP also arose because of rising food insecurity nationwide. The cost of food soared, and some foods were in short supply during the pandemic. It made it difficult for many people who lost their incomes to purchase food. Consequently, emergency food assistance programs were deluged with additional requests for food. Some food insecure individuals also sought food assistance directly from farmers. Fifty-five farm owners/operators said people sought food from them.

Some Farmers of Color may get requests for food because more of their farms are close to cities. In addition, the pandemic has affected urban Communities of Color disproportionately. There was evidence of food insecurity in such communities before the pandemic (Taylor and Ard 2015; Burdine and Taylor 2018). The emergency food requests may also be related to the expressed social mission of farms. Montri et al. (2021) found that some Michigan farmers say they enter farming to fulfill social missions. Such social missions include producing locally grown food, increasing food sovereignty in Communities of Color, or increasing access to healthy and affordable food. Some Farm Owners/Operators of Color publicly express social missions to reduce food insecurity in low-income and Communities of Color. Such messaging could result in increased requests for food during times of hardship.

Our findings suggest that food-seeking from farmers deserves further research attention. Farmers said they gave unsold produce and perishables to their friends, families, and neighbors. All the Farm Owners/Operators of Color reported that they did this. Farm owners/operators also gave away unsold produce and perishables to anyone who asked for it; they also allowed people to come to their farms and glean them. These findings suggest that farms may have social missions that are understudied.

\section{Conclusion}

This paper suggests that we should pay more attention to small family farmers to find out how disruptions to the food system, like a pandemic, strain farm operations and provide opportunities to innovate. Though the closure of restaurants posed significant challenges to farmers, study participants 
showed nimbleness and resilience by instituting social distancing procedures at their place of business, offering new delivery options, and expanding their operations. Overall, some farm owners/operators were able to enhance the financial stability of their farms.

Farmers embraced the opportunity to increase their service to emergency food assistance programs. The pandemic provided an opportunity to connect farmers to customers through new programs such as the FFFBP. Farmers should nurture these relationships after the pandemic ends.

The study identifies crucial differences between farms operated by White owners and those operated by People of Color. The findings suggest that Farmers of Color are under extra stress from demands to give away food while they have difficulty financing their farms. Moreover, Farmers of Color do not report the same access to government pandemic assistance as their White counterparts. Though Farmers of Color have risen to the occasion and provided food assistance that they are not compensated for (like gleanings and food gifting), these aspects of their social mission could be putting them at greater risk for financial insolvency. The paper suggests that researchers and policymakers pay greater attention to the inequities to ensure that Michigan has a vibrant and diverse family farming sector.

Funding The JPB Foundation and the Doris Duke Charitable Foundation.

Open Access This article is licensed under a Creative Commons Attribution 4.0 International License, which permits use, sharing, adaptation, distribution and reproduction in any medium or format, as long as you give appropriate credit to the original author(s) and the source, provide a link to the Creative Commons licence, and indicate if changes were made. The images or other third party material in this article are included in the article's Creative Commons licence, unless indicated otherwise in a credit line to the material. If material is not included in the article's Creative Commons licence and your intended use is not permitted by statutory regulation or exceeds the permitted use, you will need to obtain permission directly from the copyright holder. To view a copy of this licence, visit http://creativecommons.org/licenses/by/4.0/.

\section{References}

Agricultural Marketing Service. 2020. Local food directories: On-farm market directory. U.S. Department of Agriculture. https://www. ams.usda.gov/local-food-directories/onfarm. Accessed 26 June 2021.

Agricultural Marketing Service. 2021. USDA Farmers to Families Food Box. https://www.ams.usda.gov/selling-food-to-usda/farme rs-to-families-food-box. Accessed 26 June 2021.

Benton, T.G. 2020. COVID-19 and disruptions to food systems. Agriculture and Human Values 37: 577-578. https://doi.org/10.1007/ s10460-020-10081-1.

Black, R. and J. Jones. 2019. Benchmarking and financial comparisons of Michigan farms participating in Telfarm. October 14. https:// www.canr.msu.edu/news/benchmarking-and-financial-compa risons-of-michigan-farms-participating-in-telfarm. Accessed 14 October 2021.

Blay-Palmer, A., R. Carey, E. Valette, and M.R. Sanderson. 2020. Post COVID 19 and food pathways to sustainable transformation. Agriculture and Human Values 37: 517-519. https://doi.org/10.1007/ s10460-020-10051-7.

Burdine, J.D., and D.E. Taylor. 2018. Neighborhood characteristics and urban gardens in the Toledo metropolitan area: Staffing and voluntarism, food production, infrastructure, and sustainability practices. Local Environment 23 (2): 198-219. https://doi.org/10. 1080/13549839.2017.1397614.

Carlisle, L., M. Montenegro de Wit, M.S. DeLonge, A. Calo, C. Getz, J. Ory, K. Munden-Dixon, R. Galt, B. Melone, R. Knox, A. Iles, and D. Press. 2019. Securing the future of US agriculture: The case for investing in new entry sustainable farmers. Elementa Science of the Anthropocene 7: 17. https://doi.org/10. 1525/elementa.356.

Daniel, P. 2013. Dispossession: Discrimination against African American farmers in the age of civil rights. Durham, NC: University of North Carolina Press.

Dickinson, M. 2020. Food frights: COVID-19 and the specter of hunger. Agriculture and Human Values 37: 589-590. https:// doi.org/10.1007/s10460-020-10063-3.

Dunckel, M. 2013. Small, medium, large-Does farm size really matter. Michigan State University Extension. November 14. https://www.canr.msu.edu/news/small_medium_large_does_ farm_size_really_matter. Accessed 28 May 2021.

Emmad, F., and D.G. Pena. 2020. Feeding our autonomy: Resilience in the face of the CoVid-19 and future pandemics. Agriculture and Human Values 37: 565-566. https://doi.org/10.1007/ s10460-020-10074-0.

Farm Service Agency. 2020. Dec. 11 deadline approaching for USDA program for farmers and ranchers impacted by COVID19. https://www.fsa.usda.gov/state-offices/Michigan/michi gan-news-releases/2020/dec-11-deadline-approaching-forusda-program-for-farmers-and-ranchers-impacted-by-covid- 19 . Accessed 18 August 2021.

Galloway, M. 2020. USDA food box program helping food banks, suppliers, Michiganders. Michigan Farm News. July 31. https:// www.michiganfarmnews.com/usda-food-box-program-helpingfood-banks-suppliers-michiganders\#: :text=\%E2\%80\%9CThe $\%$ 20Farmers $\% 20$ to $\% 20$ Families $\% 20$ Food,that $\% 2$ C $\% 2 \% 80 \% 9 D \%$ $20 \mathrm{Ag} \% 20$ Secretary\%20Sonny\%20Perdue. Accessed 9 April 2021.

Hoppe, R.A. 2017. America's diverse family farms: 2017 edition. U.S. Department of Agriculture. Economic Research Service. Economic Information Bulletin 185(December). https://www. ers.usda.gov/webdocs/publications/86198/eib-185.pdf?v=2979.1. Accessed 21 February 2021.

Hoppe, R.A., J.M. MacDonald, and P. Korb. 2010. Small farms in the United States: Persistence under pressure. U.S. Department of Agriculture. Economic Research Service. Economic Information Bulletin 63(February). https://www.ers.usda.gov/webdocs/publi cations/44460/8727_eib63_1_.pdf?v=0. Accessed 9 May 2021.

Horst, M., and A. Marion. 2019. Racial, ethnic and gender inequities in farmland ownership and farming in the US. Agriculture and Human Values 36: 1-16. https://doi.org/10.1007/ s10460-018-9883-3.

IBM. 2020. IBM SPSS Statistics 27. https://www.ibm.com/support/ pages/downloading-ibm-spss-statistics-27.

Key, N., C. Burns, and G. Lyons. 2019. Financial conditions in the U.S. agricultural sector: Historical comparisons. Economic Research Service. Economic Information Bulletin, 211(October). https:// www.ers.usda.gov/webdocs/publications/95238/eib-211.pdf?v= 1595.9. Accessed 20 July 2021. 
MacDonald, J. M. 2017. Small farms, big differences. U.S. Department of Agriculture. Economic Research Service. https://www. usda.gov/media/blog/2010/05/18/small-farms-big-differences. Accessed 10 June 2021.

MacDonald, J.M., R. A. Hoppe, and D. Newton. 2018. Three decades of consolidation in U.S. agriculture. U.S. Department of Agriculture. Economic Research Service. Economic Information Bulletin 189(March). https://www.ers.usda.gov/webdocs/publications/ 88057/eib-189.pdf?v=5402.7. Accessed 25 May 2021.

MacDonald, J. M., P. Korb, P., and R. A. Hoppe. 2013. Farm size and the organization of U.S. crop farming. U.S. Department of Agriculture. Economic research report, 152 (August). https:// www.ers.usda.gov/webdocs/publications/45108/39359_err152. pdf. Accessed 22 March 2021.

Matts, C., D.S. Conner, C. Fisher, S. Tyler, and M. Hamm. 2015. Farmer perspectives of Farm to Institution in Michigan: 2012 survey results of vegetable farmers. Renewable Agriculture and Food Systems 31 (1): 60-71. https://doi.org/10.1017/S174217051 4000465.

Miller, C.L., and D. McCole. 2014. Understanding collaboration among farmers and farmers' market managers in Southeast Michigan (USA). Journal of Agriculture, Food Systems, and Community Development 4 (4): 71-95. https://doi.org/10.5304/jafscd.2014. 044.003 .

Minkoff-Zern, L.A., and S. Sloat. 2017. A new era of civil rights? Latino immigrant farmers and exclusion at the United States Department of Agriculture. Agriculture and Human Values 34 (3): 631-643. https://doi.org/10.1007/s10460-016-9756-6.

Montri, D., K. Chung, and B. Behe. 2021. Farmer perspectives on farmers markets in low-income urban areas: A case study in three Michigan Cities. Agriculture and Human Values 38: 1-14. https:// doi.org/10.1007/s10460-020-10144-3.

North Carolina Department of Agriculture. 2020. Small and minority farm program-Frequently asked questions. Office for the Small and Minority Farm Program. http://www.ncagr.gov/SmallFarms/ FAQs.htm. Accessed 29 April 2021.

Qualtrics. 2020. Qualtrics XM. https://www.qualtrics.com/.

Sielksi, J. 2020. Several Michigan companies awarded contracts for USDA Farm to Families Food Box Program. https://www.michi gan.gov/coronavirus/0,9753,7-406-98158-528880--,00.html. Accessed 20 July 2021.

Taylor, D.E. 2018. Black farmers in the USA and Michigan: Longevity, empowerment, and food sovereignty. Journal of African American Studies 22: 49-76. https://doi.org/10.1007/s12111-018-9394-8.

Taylor, D.E., and K.J. Ard. 2015. Food availability and the food desert frame in Detroit: An overview of the city's food system. Environmental Practice 17 (2): 102-133. https://doi.org/10.1017/s1466 046614000544.

Tyler, S.S., L. Rivers III, E.A. Moore, and R. Rosenbaum. 2014. Michigan black farm owners' perceptions about farm ownership credit acquisition: A critical race analysis. Race, Gender \& Class 21(3/4), 232-251. https://www.jstor.org/stable/43496994?seq=1\# metadata_info_tab_contents.

USDA. United States Department of Agriculture. 2017. Small farms, big differences. February 21. https://www.usda.gov/media/blog/ 2010/05/18/small-farms-big-differences\#: :text=USDA $\% 20 \mathrm{def}$ ines $\% 20 \mathrm{a} \% 20$ small $\% 20$ farm,cash $\% 20$ farm $\% 20$ income $\% 20$ under $\%$ $20 \% 24250 \% 2$ C000.\&text $=$ In $\% 20$ fact $\% 2 C \% 20$ all $\% 20$ of $\% 20$ the ,farms $\% 20$ under $\% 20 \% 241 \% 2 \mathrm{C} 000 \% 20 \mathrm{in} \% 20$ sales. Accessed 6 April 2021

USDA. United States Department of Agriculture. Economic Research Service. 2019. Median farm income, median off-farm income, and median total income of farm operator households, 2014-2019d, Highlights from the March 2019d Farm Income Forecast. https://www.ers.usda.gov/topics/farm-economy/ farm-sector-income-finances/highlights-from-the-farm-incomeforecast/. Accessed 7 June 2021.

USDA. United States Department of Agriculture. National Agricultural Statistics Service. 2019a. 2017 Census of Agriculture State Profile: Michigan. https://www.nass.usda.gov/Publications/AgCen sus/2017/Online_Resources/County_Profiles/Michigan/cp99026. pdf. Accessed 5 June 2021.

USDA. United States Department of Agriculture. National Agricultural Statistics Service. 2019b. 2017 Census of Agriculture highlights: Female producers. https://www.nass.usda.gov/Publications/Highl ights/2019b/2017Census_Female_Producers.pdf. Accessed 8 June 2021.

USDA. United States Department of Agriculture. National Agricultural Statistics Service. 2019c. 2017 Census of Agriculture highlights: Farm producers. https://www.nass.usda.gov/Publications/Highl ights/2019c/2017Census_Farm_Producers.pdf. Accessed 13 June 2021.

USDA. United States Department of Agriculture. National Agricultural Statistics Service. 2019d. 2017 Census of Agriculture highlights: Farm economics. https://www.nass.usda.gov/Publications/Highl ights/2019e/2017Census_Farm_Economics.pdf. Accessed 5 July 2021.

White, M.M. 2011. D-Town farm. African American resistance to food insecurity and the transformation of Detroit. Environmental Practice 13 (4): 406-417. https://doi.org/10.1017/S146604661 1000408.

White, T. and S. King. 2019. 2017 Census of Agriculture data now available. U.S. Department of Agriculture. Press release number 0051.19. https://www.usda.gov/media/press-releases/2019/ 04/11/2017-census-agriculture-data-now-available. Accessed 18 May 2021.

Whitt, C. 2021. Farm structure: Classifying diverse farms. U.S. Department of Agriculture. Economic Research Service. https://www. ers.usda.gov/topics/farm-economy/farm-structure-and-organizati on/farm-structure/\#: :text=USDA $\% 20$ defines $\% 20 \mathrm{a} \% 20$ farm $\%$ 20as,sell\%20at\%20least\%20that\%20amount. Accessed 15 June 2021

Wright, W., and A. Annes. 2016. Farm women and the empowerment potential in value-added agriculture. Rural Sociology 81 (4): 545-571. https://doi.org/10.1111/ruso.12105.

Publisher's Note Springer Nature remains neutral with regard to jurisdictional claims in published maps and institutional affiliations.

Dorceta E. Taylor is a professor and the Senior Associate Dean of Diversity, Equity, and Inclusion at the Yale School of the Environment. She is the author of Toxic Communities: Environmental Racism, Industrial Pollution, and Residential Mobility (2014), New York University Press; The Rise of the American Conservation Movement: Power, Privilege, and Environmental Protection (2016), Duke University Press; and The Environment and the People in American Cities, 1600s-1900s. Disorder, Inequality, and Social Change (2009), Duke University Press.

Lina M. Farias is a student at Colorado College.

Lia M. Kahan is a student at The College of Wooster.

Julia Talamo is a graduate student at the Yale School of the Environment. She is pursuing a master's degree in Environmental Management.

Alison Surdoval is an Agriculture and Climate Scientist at the Nature Conservancy. She has a master's degree from the University of Michigan's School for the Environment and Sustainability. 
Ember D. McCoy is pursuing a doctorate at the University of Michigan's School for Environment and Sustainability. She was formerly a Project Manager for the Doris Duke Conservation Scholars Program.

Socorro M. Daupan is an Environmental Justice Community Organizer for Clean Water Action. She earned a master's degree from the University of Michigan's School for the Environment and Sustainability, and was formerly a Program Manager for the Doris Duke Conservation Scholars Program. 